\title{
The Effect of Teacher's Ability and Student's Attitude on the Subject of Craft and Entrepreneurship to the Development of Entrepreneurship Spirit in the Implementation of Authentic Problem Based Learning
}

\author{
Munawaroh $^{1}$ \\ ${ }^{1}$ Economic Education Department of STKIP PGRI Jombang, Jombang East Java, Indonesia \\ Correspondence: Munawaroh, Economic Education Department of STKIP PGRI Jombang, Jombang, East Java, \\ Indonesia. Tel: 62-815-504-0565.E-mail: munawarohw@yahoo.co.id
}

Received: November 21, 2016

doi:10.5539/ies.v10n8p88
Accepted: March 12, $2017 \quad$ Online Published: July 29, 2017

URL: https://doi.org/10.5539/ies.v10n8p88

\begin{abstract}
Vocational high school must change student's mind set in order to be sure that they become entrepreneurs who will be better and nobler than become employees. This research aimed to determine the effect of teacher's ability in practicing the method of Authentic Problem Based Learning (APBL) and student's attitude to the development of entrepreneurship spirit based on the result of data processing that was obtained that teacher's ability in practicing the method of APBL significantly influenced the development of student's entrepreneurship spirit with coefficient as big as 0.366. Student's attitude influenced to the development of entrepreneurship spirit, with the coefficient as big as 0.179 . $\mathrm{R}^{2}$ as big as 0.208 it meant that the development of student's entrepreneurship spirit could be explained by teacher's ability variable in practicing the method of APBL and student's attitude as big as $20.8 \%$ whereas the rest was influenced by another variable which was not entered in this research.
\end{abstract}

Keywords: APBL, entrepreneurship spirit, teacher's ability, student's attitude

\section{Introduction}

Educational reform is always done to improve the quality of national education. The progress of a nation can be achieved through the reform of education both education and industry observers expressed that the quality of graduates at Vocational High Schools in Indonesia are generally still low. Being proved from the mindset and attitude of the most Vocational High School graduates still expects to work in government agencies or private, and they have not been able to or have not been dare to create jobs, at least to themselves. This case was one indicator of learning process at Vocational High School has not still been optimal. The higher the competitions are, the narrower the opportunities of Vocational High School graduates to get a job are. Paradigm of autonomy schools to implement a management of School Based Quality is one of solutions to achieve school quality targets. In this term of implementing the curriculum in 2013 and improving the quality of schools, sharing through this dialogue can provide motivation and effective innovation for teachers to create the conditions to learn a fun jointly, exciting, and educating (Enjoyable Learning) with using the learning strategies of Contextual Teaching and Learning.

Learning was able to reveal the problems and gaps of theory integration with the practice of learning evaluation (Beveridge, 2006). A lot of learning methods could be used in the learning process of Entrepreneurship. The learning methods mentioned started from the fewest students involved (Expository=exposition=lecturing teacher) up the method of the most students involved (Discovery=Inquiry=students found by themselves) among the methods of Problem Based Learning (PBL). Problem Based Learning (PBL) was an instructional approach that exemplified student centered learning. It emphasized solving complex problems in riching Contexts and aimed at developing higher order thinking skills (Savery \& Duffy, 1995; Barrows, 1996). PBL had these characteristics: (a) learning was student centered; (b) authentic problems formed the organizing focus for learning; (c) new information was acquired through self-directed learning; (d) learning focused in small groups; and (e) teachers aced as facilitators.

The successful use of Problem Based Learning (PBL) in education has sparked the interests of educators in different fields. PBL has been shown to be more effective than some traditional classroom instruction in providing opportunities for transferring knowledge and skills from the classroom to the workplace (Stepien \& 
Gallagher, 1993; Stepien, Gallagher, \& Workman, 1993). It results in better long-term content retention than traditional instruction (Norman \& Schmidt, 1992), and it supported the development of problem-solving skills (Gallagher, Stepien, \& Rosenthal, 1994; Hmelo \& Ferrari, 1997). Reviews these were primarily successful uses of non-technology based. In addition to methods of PBL there were also the methods of Authentic Problem Based Learning (APBL), a method of learning that involved the active participation of students (divided into small groups) to solve actual problems in the business world (authentic problem) which has been prepared carefully by a tutor (teacher) and providing opportunities for students to find their own answers to issues and present them in the classroom so that students found the concept of learning experiences (Neo \& Chyn, 2005).

The problems in the school environment were very complex, including the learning of craft and entrepreneurial subjects. The most of teachers have not provided the teaching patterns of authentic problem based learning so that they have not touched the sides of entrepreneurship and skill of an entrepreneur. Entrepreneurial spirit was expected to be a pattern of thinking (mindset) for younger generation in the middle of job limited supply. In the past time people assumed that entrepreneurship was an inborn talent (entrepreneurship was born, it was not made), it meant that entrepreneurship was not talent since it was born or business experience field but it could be learned and taught. Nowadays entrepreneurship is a discipline that could be learned and taught. "Entrepreneurship was not only born but it was also made", it means that entrepreneurship is not only inborn talent or business experience field, but could also be learned and taught. Each people who had the courage to make decisions could learn to be entrepreneurs, and behave like entrepreneurs. Entrepreneurship was a behavior that could ultimately be realized to be the form of concepts and theories and it was not entirely intuitive. Enhancing its role as a facilitator, motivator and aspirator has become the duty of teachers. So that students had the independence in solving problems in business. As a facilitator, teacher of craft and entrepreneurship should also have adequate ability about entrepreneurship and have the experience of entrepreneurship, so that it was easier to inculcate entrepreneurship spirit to students, therefore ideally teachers could not only give an example, but also become an example for their students.

The purpose of this research activity was to clarify whether the teacher's ability to be able to influence me and foster entrepreneurial spirit to students and whether student's attitudes affect their entrepreneurial spirit after being implemented Authentic Problem Based Learning (APBL) as a learning method at Vocational High School. According to the results of research that was conducted by Yuliati (2012) learning by APBL could improve learning outcomes in the cognitive, affective, and psychomotor. The increase mentioned was happened because APBL facilitate students to learn actively, independently with using physical phenomena directly. The research of Susiana (2012) stated that the teaching science by using APBL could enhance creativity, interpersonal relationship and concept mastery. Through reflection of their learning experience was motivated to produce higher quality work, with the hope of increasing learning outcomes which is not only in terms of cognitive knowledge, but also the improve of student's motivation and life skills such as personal skills, ability to gather information, ability to communicate orally and in writing as well as problem solving skills, responding to the challenges above, so that methods APBL for subjects of craft and entrepreneurship is developed at Vocational High School, it is expected to be able to be used to help students to make problem-solving on the subjects of craft and entrepreneurship at Vocational High School in Jombang.

\section{Method}

Research was a kind of quantitative research, which aimed to explain the influence of teacher's ability and student's attitude on the subjects of craft and entrepreneurship to the development of entrepreneurship in practicing Authentic Problem Based Learning (APBL). The subjects of research were students of SMK Negeri 1 Jombang. The total number of them data based on the majoring of Finance with the competence of Accounting Skills that were netted was 102 students. Data collection method was as observation and interviews, and questionnaires to both students and teachers. Colleced data which was analyzed by using the technique of multiple linear regression analysis to analyze the influence of teacher's ability in practicing the method of APBL on the subject craft and entrepreneurship and student's attitude to the development of entrepreneurial spirit with the following design: 


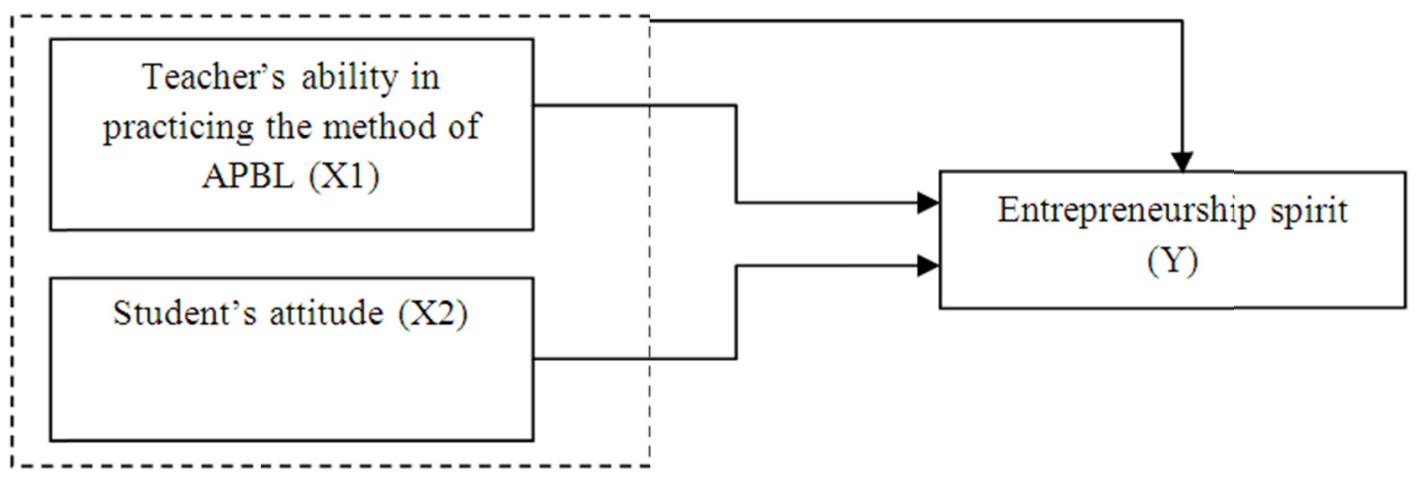

Figure 1. The design of multiple linear regression research

The formulation of Research designs multiple linear regression as follow:

$\mathrm{Y}=\mathrm{a}+\mathrm{b}_{1} \mathrm{X}_{1}+\mathrm{b}_{2} \mathrm{X}_{2}$ (Priyatno, 2009)

$\mathrm{Y}=$ dependent variabel (entrepreneurship spirit)

$\mathrm{X}_{1}$ = independent variabel (teacher's ability in practicing the method of APBL

$\mathrm{X}_{2} \quad$ independent variabel (student's attitude)

a $\quad$ Konstanta ( $Y$ value, if $\mathrm{X}_{1}$ and $\mathrm{X}_{2}=0$ )

With using the analysis of multiple linear regression which was processed by the program of SPSS, Version 20.

\section{Results}

\subsection{Classical Assumption Test Analysis}

\subsubsection{Normality Test}

The normality test of data was intended to show that the sample data came from distributed population was normal. Normality test used one Kolmogorov-Smirnov Test to generate a level of confidence (significance level), the significance criteria is $>0.05$ which means the normal distribution for all variables in this research (Amir, 2006). Normality test results were presented in the following table.

Table 1 . The result of normality test

\begin{tabular}{lccl}
\hline Independent Variable & Sig & Critical Scores & Explanation \\
\hline Ability & 0.898 & 0.05 & Normal Distribution \\
Attitude & 0.918 & 0.05 & Normal Distribution \\
Spirit & 0.945 & 0.05 & Normal Distribution \\
\hline
\end{tabular}

In the Table 1 showed that all the scores of the variable had significance scores $>0.05$ so that the data in this research had normal distributions and they were considered to be representatives of research population.

\subsubsection{The Test of Heterocedasticity}

Heterocedasticity test aimed to test whether the regression model occurred the inequality of residual variance from one observation to another observation. If the variance of the residuals from the observations to other observations that remain, it was called homoskedastisitas and if it was different so that it was called heterocedasticity. A good regression model was heterocedasticity. The method that was used to detect the presence of symptoms of heterocedasticity was Spearman rank test. And results showed that all the variables were independent to the absolute residual symptoms did not occur heterocedasticity because each independent variable had a probability value $>0.05$.

\subsubsection{Test Multicolinearity}

Multicolinearity test aimed to test whether the regression model was found a correlation between independent variables. A good regression model should not happen correlation between independent variables. 
Multicolinearity test was done by looking at the value of tolerance and variance inflation factor (VIF) from the results of analysis by using SPSS. If the value of tolerance $>0.10$ or VIF $<10$ meant it did not happen multicolinearity (Santoso, 2004). The value of VIF in this research could be seen in table 2.

Table 2. The results of multicolinearity test

\begin{tabular}{lcc}
\hline Independent Variable & Tolerance & Critical Value \\
\hline Model 1 & 0.284 & 0.10 \\
Model 2 & 0.159 & 0.10 \\
\hline
\end{tabular}

In Table 2 showed that the symptoms of multicollinearity between independent variables did not occur because each variable had a value of tolerance $>0.10$. It could be concluded that it did not occur the irregularities of classical assumptions multicollinearity between independent variables.

\subsection{Multiple Linear Regression Analysis}

Multiple linear regression analysis was to analyze the influence of teacher's ability in practicing the method of Authentic Problem Based Learning (APBL) on the subject of craft and entrepreneurship and student's attitude to entrepreneurship spirit. Multiple linear regression analysis that was used to test this research hypothesis was test $\mathrm{t}$ and multiple linear regression $\mathrm{F}$. The results of multiple linear regression analysis in this research were presented in table below.

Table 3. The conclusion of regression analysis results

\begin{tabular}{lccccc}
\hline Model & $\begin{array}{c}\text { Koef. } \\
\text { Regression }\end{array}$ & $\mathrm{F}$ & $\mathrm{T}$ & Sig. & $\mathrm{R}^{2}$ \\
\hline Model1: $\mathrm{X}_{1} \mathrm{X}_{2}$ to $\mathrm{Y}_{1}$ & & 0.353 & & 0.0486 & \\
$\mathrm{X}_{1}: \mathrm{b}_{1} \mathrm{Y}_{1} \mathrm{X}_{1}$ & 0.366 & & 0.597 & 0.003 & \multirow{2}{*}{0.208} \\
$\mathrm{X}_{2}: \mathrm{b}_{2} \mathrm{Y}_{1} \mathrm{X}_{2}$ & 0.179 & & 0.291 & 0.001 & \\
\hline
\end{tabular}

Model 1:

The equation of multiple linear regression analysis in this research as follow:

Equation: $\mathrm{Y}=0.366 \mathrm{X}_{1}+0.179 \mathrm{X}_{2}$

The influence of Competence towards entrepreneurship spirit as big as 0.366 .

The influence of attitude towards entrepreneurship spirit as big as 0.179 .

The influence of competence and attitude towards entrepreneurship spirit as big as 0.208.

Based on the statistical tables that have been previously listed, it could be concluded that when the overall of $\mathrm{F}$ test model 1 has been carried out, it was clearly seen that, overall, independent variables that were used significantly with $\alpha=5 \%$. The table above showed that this model had a probability of F Statistics as big as 0.366 meant that models that were used could be said to have been relatively good. The picture of complete structural relationship as follows:

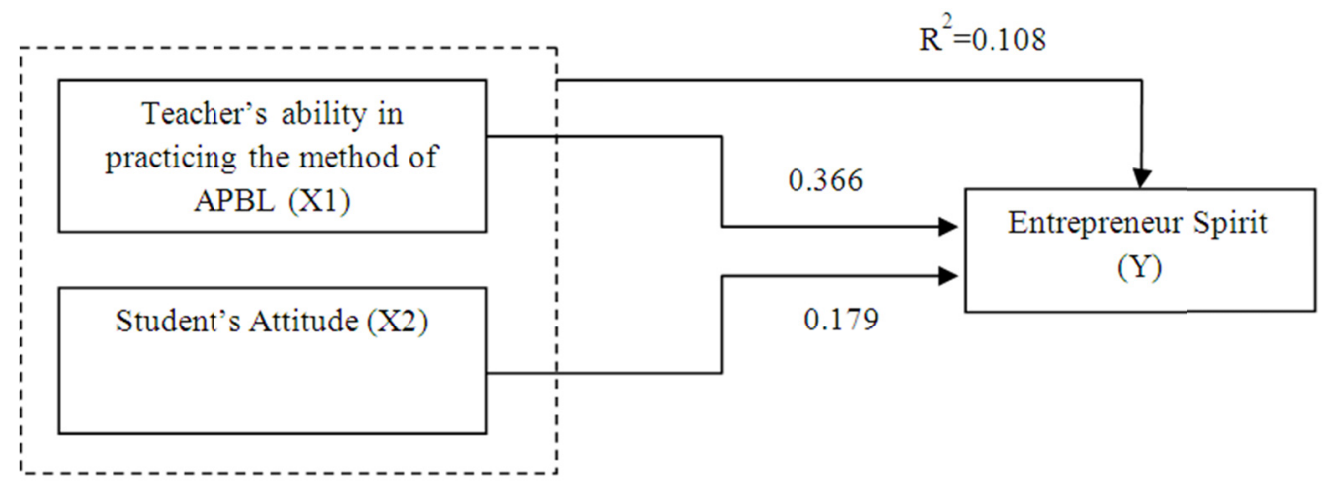

Figure 2. Complete structural relationships 
Model 2: Equation:

The influence of ability towards entrepreneurial spirit as big as 0.366 .

$\mathrm{X} 1 \rightarrow \mathrm{Y}=0.366$.

The influence of attitudes towards entrepreneurial spirit as big as 0.179 .

$\mathrm{X} 2 \rightarrow \mathrm{Y}=0.179$.

The influence of total ability variables and attitude towards entrepreneurial spirit.

$\mathrm{R}^{2}=1-\{(1-0108)\}=1-\{(0893)\}=0.108$.

The variables that influenced the most to the entrepreneurial spirit was a variable that was teacher's variable ability as big as 0.366 .

Regression 1: $\sqrt{ }=\sqrt{ }=0.995$

It meant that the diversity of data that could be explained by linear regression model mentioned it was amounted to 0.995 or $99.5 \%$, or in other words, the information that was contained in the data of $99.5 \%$ could be explained by the model mentioned. Whereas $0.5 \%$ was explained by other variables that have not been included in this research.

\subsection{Hypothesis Test}

\subsubsection{Partial Test (t-test)}

Partial test results were t-test. Where the partial test was used to see the influence of all independent variables (Teacher's ability, student's attitudes) individually (partially) to the dependent variable (entrepreneur spirit). The test results could be seen in count. Ho was accepted if count $t<t$ table and Ho hypothesis was rejected if count $>$ $\mathrm{t}$ table at the confidence level $95 \%$ or error rate $\alpha=0.05$. Principal problems that were discussed in the research, the researcher made several hypotheses to know how big the influence of variables in the research. $T$ test was used to determine whether a significant difference between the independent variable (Y). Based on the multiple linear regression analysis on the table was. Obtained by regression analysis as follows:

1) The influence of teacher's ability in practicing the method of Authentic Problem Based Learning (APBL) to entrepreneurship spirit.

The results of multiple linear regression analysis on the table, the variable ability of teachers as big as 0.366 , it meant that if the ability of teachers increased as big as one unit so that the entrepreneurial spirit rose as big as 0.366 with assuming other variables remained. At the significance level $5 \%$, so that research sig value $(0.003)$ $<0.05$ so that research hypothesis was accepted, hypothesis test result indicated that the ability of teachers effected on entrepreneurial spirit positively and significantly. The better the ability of the students were positive and significant to the development of entrepreneurial spirit. The better the teacher's ability was the more development of student's entrepreneurship spirit.

2) The effect of students' attitude partially to the development of entrepreneurial spirit.

The results of multiple linear regression analysis on the tables, student's variable attitudes as big as 0.179 , it meant that if the attitude of entrepreneurs increased as big as one unit so that the entrepreneurial spirit rose as big as 0.179 with assuming other variables remained. At a significance level $5 \%$, with significant value of research $(0.001)<0.05$ so that the research hypothesis was accepted. Hypothesis test results showed that student's attitudes impacted on positive and significant to the student's entrepreneurial spirit, The better the student's attitude was, the better the entrepreneurial spirit was.

\subsubsection{Test of $F$}

Test that was conducted to determine the effect of teacher's ability and entrepreneurial attitude towards entrepreneurial spirit by using The Statistical test of F. Criteria that was established for expressing the linearity of regression line, namely if the value of $\mathrm{F}$ statistic test, count $<\mathrm{F}$ table, so that Ho was accepted and Ha was rejected. Or on the contrary, if the result of F statistical test, Count $>$ F table, so that Ho was rejected and Ha was accepted. The results of $F$ test could be seen in table 4. 
Table 4. The result of $\mathrm{F}$ test

\begin{tabular}{lccccc}
\hline & $\begin{array}{c}\text { Sum of } \\
\text { square }\end{array}$ & df & $\begin{array}{c}\text { Mean } \\
\text { Square }\end{array}$ & F & Sig. \\
\hline Regression & 0.040 & 2 & .020 & 0.179 & .846 \\
Residual & 0.334 & 3 & .111 & & \\
Total & 0.373 & 5 & & & \\
\hline
\end{tabular}

The results of count $F$ test as big as 0,179 with the sig. as big as 0,846 , with using a trust level as big as $95 \%$ or $\alpha$ $=0.05$. So that from F distribution table showed that sig value $(0,846)>\alpha(0.05)$. From these results mentioned, so that it could be taken an analysis decision that the linear regression model, which meant simultaneously that the variables of teacher's ability and attitudes impacted to the growth of an entrepreneurial spirit.

\subsection{The Result of Interview with Teacher Who Educated the Subjects of Craft and Entrepreneurship}

The results of interviews with teachers who educated the subject of craft and entrepreneurial as follows:

The learning materials of craft and entrepreneurial followed the syllabus and lesson plans that have been established by the institutions and the government, where learning the craft and entrepreneurship was not only a theory, but should be able to marry between theory and practical world business.

There were several stages in the process of learning the craft and entrepreneurship that have implemented Authentic Problem Based on Learning, namely, included: (a) changing the student's cerebration about entrepreneurship; (b) basic concepts and theories of entrepreneurship; (c) seeking and studying the success stories of entrepreneurs especially those people who still started entrepreneurship since they were in the school it is intended that the students could imitate their trail; (d) making a simple business plan; (e) trying both group and individual entrepreneurship; and (f) interviewing with successful entrepreneurs in a group, then presenting, as well as following up for students after studying with successful entrepreneurs.

1) The methods of entrepreneurial learning that have been done: discussion, case studies, individual and group assignments, presentations and simulations.

2) Learning media include: LCD Projector, tools and whiteboards, internet, movies motivation and success stories, slide presentations (power point), product sampling, success stories were recorded.

\section{Discussion}

The results of research showed that the teacher's ability practiced the method of Authentic Problem Based Learning (APBL) to take more influences to be proved by the value of coefficient as big as 0.366 was compared by student's attitude with value as big as 0.179 in growing entrepreneurship spirit. Therefore preneuriel education at High Vocational School had to be taught by professional teacher who have learning ability about a craft and entrepreneurship both theory and filed practice.

Whereas the value of $R^{2}$ as big as 0.208 , it meant that the development of $R^{2}$ student's entrepreneour spirit can be explained by teacher's abiliyty variable in practicing.

The method of Authentic Problem Based Learning (APBL) and student's attitude as big as $20.8 \%$ whereas the rest was influenced by another variable that was not entered in this research. This research was suitable with the result of research from Alafiatayo, Anyanwu, and Salau (2016) that indicated significant relationships between the teacher variables and students' academic achievement in Biology. Also $64.5 \%$ of the variance observed in students' achievement in biology was explained by linier combination of the five-predictor variables. Students' attitude was the most potent contributor while teachers' workload was the least contributor to the prediction. Whereas the result of research according to Etherington (2011) with the title of "Investigative Primary Science": A Problem-based learning Approach who stated that the PBL course had a positive impact on the pre-service teachers' motivation to teach science ideas within a real world context.

The subject of craft and entrepreneurship was vocational lesson, namely subject that was used to give knowledge, attitude and job skills for student. Competence that was expected could do economic productive activity after they get in to job world. The success of business depended on market. Market consists of internal market namely employee, organization, and external market, namely product buyer that we sold. Therefore in learning the subject of craft and entrepreneurship must pay attention on characteristic as follow: (1) learning by doing meant that the learning principle of craft and entrepreneurship was learning by doing, so that students had a practical learning experience; (2) As far as possible what was learned in the same school that would be performed in the job world, so that the knowledge, attitude and practice skills that were learned were not different from something 
that was performed in real terms in the community; and (3) operational practice experience that was learned was greater portion than the conceptual cognitive knowledge.

As subjects that had the characteristics that emphasized on social needs and psyche of the human psyche, so that learning the craft and ideally entrepreneurship ideally also used the humanist approach. Namely learning that puts students as human beings that were composed of body and soul. The goal was in order that the learning process became a vehicle for appreciating human by humanist, because in the entrepreneurship in the future they will be dealing directly with other people as job partners. The approach of humanist was a method that was able to meet the needs of students as human beings.

Whereas the approach which was used had to be different from traditional approach (teacher style teaching) and had to be changed with action learning approach. One of methods that could be used in learning the subject of craft and entrepreneurship was the method of Authentic Problem Based Learning (APBL). The steps in APBL method as follows: (1) forming a group. Teachers formed groups and defined roles, each member of the group was divided by the discussion leader, secretary and members; (2) forming tutor. Teachers formed tutor (who has understood correctly about the problem which would be studied) to assist in informal discussion groups; (3) Problem Submission. Teachers delivered "business problems" that should be discussed by each group as a focus for student's learning; (4) investigation. Students conducted an investigation (searching for information, exploration, experiment, and choosing approach to solve the problem that they talked over; (5) clarifying the problem. Tutor guided the group for doing reflection (contemplation) on an action plan that would be done to solve the problem; (6) identifying the problem. Students summarized related problems and determined the main cause of the problem; (7) diagnostics discussion. Students discussed the findings of the strategy and resources information that must be searched to find the facts. To tutor, students reported actual sources that they used to solve the problem; (8) decision-making. Students made the final decision about solving the problem. Tutor constantly checked and tested the decisions that were taken by the students; (9) production. Students wrote down solutions to the problems that have been solved together; (10) presentations. Students made presentations in plenary to convey the idea of solving the problems that they have generated in group discussions; (11) arranging a concept map. Having been presented the students put the integrative overview of steps and results of problem solving in the form of schematic drawings or charts; and (12) assessment. Students assessed their own learning success. In addition the group also got an appraisal as well as criticism from other groups and from tutors.

Education with the method of Authentic Problem Based Learning (APBL) had to use a variety of real problems so that students learned to think critically and skillfully to solve problems and to support the development of technical skills and also got deep knowledge acquisition. On the learning method of Authentic Problem Based Learning focused on: (1) delivering problem (2) solving real problems, (3) working group, (3) investigation, (4) clarification of problem (5) identify the problem (6) discussion (7) presentation, (8) developing a concept map, and (9) ratings.

The main goal of this method was not only to find solutions, but also aimed in order that students learned the concepts and the way to make problem solving and developed critical thinking abilities. In studying the concepts and the capabilities of critical thinking mentioned, they worked together in the groups to assess the real problems in the real business activities. In the mechanism of this group would occur dialogue of give and take among the group's members in order to obtain a realistic and adequate understanding so that it could be applied in the field.

\section{Conclusion}

There was Influence either partially or simultaneously teacher's ability in practicing the methods of APBL and student's attitude to the development of entrepreneurship spirit that was demonstrated by sig $t$ as big as 0.003 and $0.001<0.05$ and sig. $\mathrm{F}$ as big as $0.0486<0.05$.

Teacher's ability was very influential on the growth of student's entrepreneurial spirit. It is quite possible that the emergence of a right thinking way about entrepreneurship for students and the emergence of students' attitudes towards entrepreneurship were also caused by teacher's ability that were professionals in the art. Therefore it could be studied in the future studies.

\section{Suggestions}

A teacher of craft and entrepreneurship had better as business conductors, so that they had the abilities in theory and practice and they were able to combine both of them.

The orientation learning of craft and entrepreneurial subjects could be able to grow the way of thinking and entrepreneur spirit for the students, so that students consciously had the courage to try entrepreneurship. Therefore, the approach must not only theory but also with case study and practice (learning by doing), with 
teacher or mentor's guidance that was innovative in learning and taught the subjects of craft and entrepreneurial one of them was with practicing the method of Authentic Problem Based Learning (APBL).

\section{References}

Alafiatayo, B. M., Anyanwu, R. I., \& Salau, O. S. (2016.) Effect of selected teachers'abilities on students'attitudes and academic performance in biology among secondary schools in Sabongari local government area, Kaduna State, Nigeria. IOSR Journal of Research \& Method in Education, 6(2), 24-29. https://doi.org/10.9790/7388-0602032429

Amir, F. M. (2006). Mengolah dan membuat interprestasi hasil olahan SPSS untuk penelitian ilmah. Jakarta, Indonesia: Edsa Mahkota.

Barrows, H. S. (1996). Problem-based learning in medicine and beyond: A brief overview. New Directions for teaching and learning, 68, 3-12. https://doi.org/10.1002/t1.37219966804

Beveridge, A. A. J. (2006). Motivational implications of project-based learning for thepreparation of social workers. Paper presented at the annual meeting of the Australian Association for Researching Education. Adelaide, November 27-30.

Etherington, M. B. (2011). Investigative primary science: A problem-based learning approach. Australian Journal of Teacher Education, 36(9), 53-74. https://doi.org/10.14221/ajte.2011v36n9.2

Gallagher, S. A., Stepien, W. J., \& Rosenthal, H. (1994). The effects of problem-based learning on problem solving. Gifted Child Quarterly, 36, 195-200. https://doi.org/10.1177/001698629203600405

Hmelo, C. E., \& Ferrari, M. (1997).The problem based learning tutorial: Cultivating higher order thingking skills. Journal for the Education of the Gifted, 20(4), 401-422. https://doi.org/10.1177/016235329702000405

Neo, L. W. K., \& Chyn, M. K. Y. (2005). Authentic problem based learning: Rewriting business education. Singapore: Pearson Education Asia.

Norman, G. R., \& Schmidt, H. G. (1992). The psychological basis of problem-based learning: A review of the evidence. Academic Medicine, 67, 557-565. https://doi.org/10.1097/00001888-199209000-00002

Priyatno, D. (2009). SPSS untuk analisis korelasi, regresi dan multivariate. Yogyakarta, Indonesia: Gaya Media.

Santoso, S. (2004). SPSS versi 11 mengolah data statistik secara profesional. Jakarta, Indonesia: PT Elex Media Komputindo.

Savery, J. R., \& Duffy, T. M. (1995). Problem based learning: An instructional model and its constructivist framework. Educational Technology, 35, 31-38.

Stepien, W. J., Gallgher, S. A., \& Workman, D. (1993). Problem-based learning for traditional and interdisciplinary classrooms. Journal for education of the Gifted, 16(4), 338-357. https://doi.org/10.1177/016235329301600402

Stepien, W., \& Gallagher, S. (1993). Problem-based learning: As authentic as it gets. Educational Leadership, 50(7), 25-28. Retrieved from http://www.ascd.org/publications/educational_leadership/apr93/vol50/num07/ Problem-Based_Learning@_As_Authentic_As_It_Gets.aspx

Susiana, N. (2012). The application of APBL (authentic problem based learning) to enhance generic entrepreneurial competencies in a basic chemistry course. Retreived from http://wwwdavidpublishing.com/ download/id=6159

Yuliati, L. (2012). Authentic problem based leaqrning untuk meningkatkan hasil belajar Fisika siswa SMA. Makalah, Seminar Nasional MIPA dan Pembelajaran. Fakultas Matematika dan Ilmu Pengetahuan Alam. Malang, Indonesia: Universitas.

\section{Copyrights}

Copyright for this article is retained by the author(s), with first publication rights granted to the journal.

This is an open-access article distributed under the terms and conditions of the Creative Commons Attribution license (http://creativecommons.org/licenses/by/4.0/). 